University of Nebraska - Lincoln

DigitalCommons@University of Nebraska - Lincoln

Biological Systems Engineering: Papers and

Publications

Biological Systems Engineering

$1-2003$

\title{
Influence of Sorghum Wax, Glycerin, and Sorbitol on Physical Properties of Soy Protein Isolate Films
}

\author{
Ki Myong Kim \\ University of Nebraska-Lincoln \\ David B. Marx \\ University of Nebraska-Lincoln, david.marx@unl.edu \\ Curtis Weller \\ University of Nebraska-Lincoln, cweller1@unl.edu \\ Milford Hanna \\ University of Nebraska-Lincoln, mhanna1@unl.edu
}

Follow this and additional works at: https://digitalcommons.unl.edu/biosysengfacpub

Part of the Biological Engineering Commons

Kim, Ki Myong; Marx, David B.; Weller, Curtis; and Hanna, Milford, "Influence of Sorghum Wax, Glycerin, and Sorbitol on Physical Properties of Soy Protein Isolate Films" (2003). Biological Systems Engineering: Papers and Publications. 197.

https://digitalcommons.unl.edu/biosysengfacpub/197

This Article is brought to you for free and open access by the Biological Systems Engineering at DigitalCommons@University of Nebraska - Lincoln. It has been accepted for inclusion in Biological Systems Engineering: Papers and Publications by an authorized administrator of DigitalCommons@University of Nebraska Lincoln. 


\title{
Influence of Sorghum Wax, Glycerin, and Sorbitol on Physical Properties of Soy Protein Isolate Films
}

\author{
Ki Myong Kim, ${ }^{1}$ David B. Marx, ${ }^{2}$ Curtis L. Weller, ${ }^{1}$ and Milford A. Hanna ${ }^{1}$ \\ 1. Industrial Agricultural Products Center, University of Nebraska-Lincoln, Lincoln, Nebraska 68583 \\ 2. Department of Biometry, University of Nebraska-Lincoln, Lincoln, Nebraska 68583 \\ Corresponding author - C. L. Weller, Industrial Agricultural Products Center, University of Nebraska, \\ 208 L. W. Chase Hall, Lincoln, NE 68583-0730; email cweller1@unl.edu
}

\begin{abstract}
Sorghum wax, sorbitol, glycerin, and soy protein isolate (SPI) composite films were prepared. Effects of sorghum wax, sorbitol, and glycerin concentrations on various films were evaluated using response surface methodology. All independent variables significantly $(P<$ 0.05) affected film water vapor permeability (WVP), tensile strength (TS), elongation at break (E), total color difference, and total soluble matter (TSM). Increasing the sorghum wax concentration decreased WVP and E. As sorbitol content increased in the composite films, WVP and TS increased. Sorbitol had a critical point of 2-5 g/5 g SPI for low values of TSM. The addition of sorbitol contributed more to the properties of the film than did glycerin.
\end{abstract}

Keywords: Edible films, RSM design, sorghum wax, soy protein isolate, water vapor permeability.

Hydrophilic edible films, including protein films, provide barriers to oxygen and carbon dioxide and are friendly to the environment because of their degradibility and renewability. However, they have higher water vapor permeability and weaker mechanical properties than synthetic films. Poor performance as a water vapor barrier is one of the main limitations of protein films. This is attributed to the hydrophilic nature of proteins and to the considerable amount of hydrophilic plasticizers typically incorporated into protein films (1).

One way of improving moisture barrier properties of protein films is to include additives that are hydrophobic in nature. Accordingly, lipidic materials such as neutral lipids, FA, or waxes have been incorporated into protein films. Hydrophobic lipids, such as neutral lipids of glycerides, longchain FA, waxes, resins, oils, and surfactants, exhibit good moisture barrier properties. Composite protein-lipid films, in a laminated or an emulsified form, may be prepared so as to combine the good structural and oxygen barrier properties of protein films with the good moisture barrier characteristics of lipids (2).

Cast protein-lipid films have been reported to have lower water vapor permeability (WVP) values than control protein films produced using caseinates (3), whey protein (4), wheat gluten (5), or zein (6). It is well known to film scientists that protein-lipid composite films are difficult to prepare, requiring additional processing such as heating and homogenizing. Lipid materials are not miscible in aqueous film-forming solutions. Most experiments have been performed with refined lipid materials. Unrefined wax, which naturally contains some extraneous polar and hydrophilic materials, may be more miscible in an aqueous film-forming solution than refined wax. Wax recovered from extraction with ethanol contains some hydrophilic materials (7). Therefore, wax of unrefined origin may serve as a useful additive to improve the water vapor barrier properties of protein films. It likely would be less expensive than refined wax, and its extraneous material would aid film formation.

Glycerin, as a plasticizer, increases not only film flexibility but also WVP. Polyols, such as sorbitol, plasticize effectively due to their ability to reduce internal hydrogen bonding while increasing intermolecular spacing. Sorbitol was reportedly very compatible with glycerin in soy protein isolate (SPI) films or wheat gluten films. Sorbitol was more effective at smaller added amounts than glycerin as a plasticizer in casein films of equal mechanical properties such as tensile strength (TS) and elastic modulus (8).

The objective of this study was to gain a better understanding of plasticizer influences on properties of SPI film under different unrefined grain sorghum wax concentrations. The effects and interactions of various levels of sorghum wax, glycerin and sorbitol on WVP, TS, elongation at break $(\mathrm{E})$, total color difference $(\Delta \mathrm{E})$, and total soluble matter (TSM) of films were studied using response surface methodology.

\section{Materials and Methods}

Statistical design. A response surface experiment was designed to identify the relationships between three independent variables - content of sorghum wax (\%, w/w protein, $\left.X_{1}\right)$, sorbitol $\left(\mathrm{g} / 5 \mathrm{~g}\right.$ protein, $\left.X_{2}\right)$, and glycerin $(\mathrm{g} / 5 \mathrm{~g}$ protein, $X_{3}$ )-and measured film properties. The specific experimental design adopted was a central composite response surface design (9). The independent variables were coded as $-a,-1,0,1$ and $a$. The actual values of the independent variables were chosen based on preliminary studies, and the corresponding coded values of independent variables are given in Table 1. The complete design consisted of 19 experimental points that included five center points. Treatments from one to eight were tested in duplicate. Films were prepared in random order. Responses or film property values under 
Table 1. Response Surface Level Combinations of Independent Variables in the Experimental Design and Responses of Dependent Variables

\begin{tabular}{|c|c|c|c|c|c|c|c|c|c|}
\hline $\begin{array}{l}\text { Design } \\
\text { point }\end{array}$ & \multicolumn{3}{|c|}{ Independent variable } & \multicolumn{6}{|c|}{ Dependent variable } \\
\hline $1 \mathrm{~g}$ & $-1(6.08)$ & $-1(2.03)$ & $-1(1.01)$ & 19.25 & 6.18 & 4.58 & 89.37 & 18.33 & 91.56 \\
\hline $2 g$ & $-1(6.08)$ & $-1(2.03)$ & $1(3.98)$ & 41.92 & 14.80 & 1.07 & 139.23 & 18.41 & 52.57 \\
\hline $3 g$ & $-1(6.08)$ & $1(7.97)$ & $-1(1.01)$ & 19.59 & 11.0 & 0.79 & 109.25 & 18.51 & 100.68 \\
\hline $6^{g}$ & $1(23.9)$ & $-1(2.03)$ & $1(3.98)$ & 39.60 & 6.11 & 2.03 & 48.04 & 23.39 & 50.23 \\
\hline $7 \mathrm{~g}$ & $1(23.9)$ & $1(7.97)$ & $-1(1.01)$ & 17.13 & 8.14 & 1.17 & 70.91 & 22.09 & 88.43 \\
\hline $8^{g}$ & $1(23.9)$ & $1(7.97)$ & $1(3.98)$ & 28.61 & 13.67 & 0.44 & 74.85 & 22.51 & 67.99 \\
\hline 9 & $-a(0.00)$ & $0(5.00)$ & $0(2.50)$ & 25.87 & 18.54 & 0.9 & 217.00 & 22.54 & 61.06 \\
\hline 10 & $\alpha(30.0)$ & $0(5.00)$ & $0(2.50)$ & 23.95 & 7.79 & 1.74 & 69.81 & 23.66 & 46.42 \\
\hline 11 & $0(15.0)$ & $-a(0.00)$ & $0(2.50)$ & 29.44 & 5.35 & 9.42 & 20.56 & 23.88 & 25.91 \\
\hline $16^{\mathrm{h}}$ & $0(15.0)$ & $0(5.00)$ & $0(2.50)$ & & 10.96 & 1.29 & 122.12 & 25.30 & 57.21 \\
\hline $17^{\mathrm{h}}$ & $0(15.0)$ & $0(5.00)$ & $0(2.50)$ & $23.82^{\mathrm{i}}$ & 11.12 & 1.23 & 103.73 & 24.97 & 53.87 \\
\hline $18^{\mathrm{h}}$ & $0(15.0)$ & $0(5.00)$ & $0(2.50)$ & & 8.81 & 1.41 & 104.57 & 25.58 & 56.67 \\
\hline $19^{\mathrm{h}}$ & $0(15.0)$ & $0(5.00)$ & $0(2.50)$ & & 8.02 & 1.31 & 84.21 & 25.86 & 60.73 \\
\hline
\end{tabular}

a. Moisture content, mean of three replications.

b. Water vapor permeability (WVP) expressed $\mathrm{g} \cdot \mathrm{m} / \mathrm{m}^{2} \cdot \mathrm{h} \cdot \mathrm{Pa}$, mean of three replications.

c. Tensile strength (TS), mean of five replications.

d. Elongation at break (E), mean of five replications.

e. Total color difference $(\Delta \mathrm{E})$, mean of ten replications.

f. Total soluble matter (TSM), mean of three replications.

g. Mean of two replications from 1-8 design points.

h. Central points.

i. Mean of five central points.

observations were WVP, TS, E, TSM, and $\triangle \mathrm{E}$. Data were analyzed to fit the following third-order equation for each response variable:

$$
\begin{aligned}
Y=b_{0} & +b_{1} X_{1}+b_{2} X_{2}+b_{3} X_{3}+b_{12} X_{1} X_{2}+b_{13} X_{1} X_{3} \\
& +b_{23} X_{2} X_{3}+b_{123} X_{1} X_{2} X_{3}+b_{11} X_{1}{ }^{2}+b_{22} X_{2}{ }^{2} \\
& +b_{33} X_{3}^{2}+b_{111} X_{1}^{3}+b_{222} X_{2}^{3}+b_{333} X_{3}^{3}
\end{aligned}
$$

where the $b_{n}$ values were regression coefficients and $X_{1}, X_{2}$, and $X_{3}$ were the coded independent variables. All statistical calculations were performed using the SAS/STAT ${ }^{\mathrm{TM}}$ statistical package (10).

Extraction of wax. Approximately $800 \mathrm{~g}$ of whole grain sorghum (red sorghum: Golden Harvest H512 harvested in Lancaster County, Nebraska, in 1996) was mixed with approximately $800 \mathrm{~mL}$ of ethanol $(99.5 \%)$ in a 2-L round-bottomed flask, heated to the boiling point of ethanol, and refluxed for $30 \mathrm{~min}$. Vacuum filtration was performed using a 2-L side-armed Erlenmeyer flask attached to a 16-cm Büchner funnel (Coors 60246) fitted with a Whatman No. 2 filter paper (Whatman International Ltd., England) and overlaid with a coffee filter to remove impurities. The filtrate was collected and stored at $-18^{\circ} \mathrm{C}$ for at least $8 \mathrm{~h}$ to precipitate the wax. Filtrates containing wax precipitates were filtered using a 10-cm Büchner funnel (Coors 60243) fitted with Whatman No. 42 filter paper. It is important to note that not all of the ethanol passed through the filter paper. Some remained with the wax, creating a wax/ethanol paste (unrefined wax) containing $2-3 \%$ wax. Wax/ethanol paste was stored at $-18^{\circ} \mathrm{C}$ in cap-sealed bottles until it was used for film preparation.

Film preparation. Film-forming solutions were prepared by mixing $100 \mathrm{~mL}$ of distilled water and $5 \mathrm{~g}$ of SPI (Supro 620; Protein Technologies International, St. Louis, MO). Glycerin (USP grade; Mallinckrodt, Paris, KY), sorbitol (crystalline sorbitol, SORBOGEM ${ }^{\mathrm{TM}}$; SPI Polyols, Inc., New Castle, DE) and wax were added at levels consistent with the response surface design, on a dry basis. Sodium hydroxide (2 $\mathrm{N})$ was used to adjust the solution $\mathrm{pH}$ to $10.00 \pm 0.01$. Then, solutions were held for $15 \mathrm{~min}$ in a $75^{\circ} \mathrm{C}$ water bath and strained through cheesecloth (Cheesecloth Wipes ${ }^{\mathrm{TM}}$; VWR Scientific Products, Chicago, IL) to remove any bubbles and lumps (only minuscule amounts were present). The filmforming solutions were cast on flat, level, Teflon ${ }^{\circledR}$-coated glass plates $(21 \times 35 \mathrm{~cm})$. Films were peeled from the plates after drying at room temperature for $20 \mathrm{~h}$. Dried films were conditioned at $50 \% \mathrm{RH}$ and $25^{\circ} \mathrm{C}$ for $48 \mathrm{~h}$. 
Thickness. Film thickness was measured to the nearest $2.54 \mu \mathrm{m}(0.1 \mathrm{mil})$ with a hand-held micrometer (B.C. Ames Co., Waltham, MA). Five thickness measurements were taken on each WVP specimen, one at the center and four around the perimeter, and the mean was used in the WVP calculation. For TS calculations, five thickness measurements were taken along the length of each specimen, and the mean was used in calculating film TS.

Color. Color values of films were measured using a portable colorimeter (CR-300 Minolta Chroma Meter; Minolta Camera Co., Osaka, Japan). Film specimens were placed on a white plate and the HunterLab color scale was used to measure color: $L=0$ to 100 (black and white), $a=-80$ to 100 (greenness and redness), and $b=-80$ to 70 (blueness and yellowness). Standard values for the white calibration plate were $L=96.86, a=-0.07$, and $b=1.98$. The change of color was evaluated by comparing total color differences between films. $\Delta \mathrm{E}$ was calculated as:

$$
\begin{array}{r}
\Delta \mathrm{E}=\left[\left(L_{\text {standard }}-L_{\text {sample }}\right)^{2}+\left(a_{\text {standard }}-a_{\text {sample }}\right)^{2}\right. \\
\left.+\left(b_{\text {standard }}-b_{\text {sample }}\right)^{2}\right]^{1 / 2}
\end{array}
$$

Color measurements for each type of film were replicated five times.

TS and \%E at break. TS and E were both measured with an Instron Universal Testing Machine (Model 5566; Instron Corp., Canton, MA) following the guidelines of ASTM Standard Method D882-91 (11). Initial grip separation was set at $50 \mathrm{~mm}$, and cross-head speed at $500 \mathrm{~mm} / \mathrm{min}$. TS was expressed in $\mathrm{MPa}$ and calculated by dividing the maximum load $(\mathrm{N})$ by the initial cross-sectional area $\left(\mathrm{m}^{2}\right)$ of the specimen. E was calculated as the ratio of the final length of the point of sample rupture to the initial length of a specimen (50 $\mathrm{mm})$, as a percentage. TS and E tests for each type of film were replicated five times.

TSM. TSM was expressed as the percentage of film dry matter dissolved during immersion in distilled water for 24 h. Film pieces $(20 \times 20 \mathrm{~mm})$ were placed in 50 -mL beakers containing $30 \mathrm{~mL}$ of distilled water. Beakers were covered with Parafilm ${ }^{\mathrm{TM}}$ ' $\mathrm{M}^{\prime}$ wrap (American National Can, Chicago, IL) and stored at $25^{\circ} \mathrm{C}$ for $24 \mathrm{~h}$. Dissolved dry matter was determined by discarding the water from the beakers and drying the remaining film specimen in an air-circulating oven $\left(105^{\circ} \mathrm{C}\right)$ for $24 \mathrm{~h}$. The weight of dissolved dry matter was calculated by subtracting the weight of insoluble solid matter from the initial weight of solid matter (12). TSM tests for each type of film were replicated three times.

WVP. Five film specimens were tested for each type of film. WVP $\left(\mathrm{g} \cdot \mathrm{m} / \mathrm{m}^{2} \cdot \mathrm{h} \cdot \mathrm{Pa}\right)$ was calculated as:

$$
\mathrm{WVP}=(\mathrm{WVTR} \cdot l) / \Delta p
$$

where WVTR was measured water vapor transmission rate $\left(\mathrm{g} / \mathrm{m}^{2} \cdot \mathrm{h}\right)$ through a film specimen, $l$ was mean film specimen thickness $(\mathrm{m})$, and $\Delta p$ was partial water vapor pressure difference $(\mathrm{Pa})$ between the two sides of the film specimen. WVTR was determined gravimetrically using a modification of ASTM Method E 96-95 (13). Film specimens were mounted on polymethylmethacrylate cups filled with $16 \mathrm{~mL}$ of distilled water up to $1.03 \mathrm{~cm}$ from the film underside. Cups were placed in an environmental chamber set at $25{ }^{\circ} \mathrm{C}$ and $50 \%$ RH. A fan was operated in the chamber to move the air with a velocity of $196.3 \mathrm{~m} /$ min over the surface of the films to remove the permeating water vapor. The weights of the cups were recorded six times at 1 -h intervals. Linear regression was used to estimate the slope of this line in $\mathrm{g} / \mathrm{h}$. WVP was calculated by corrective equation (14).

\section{Results and Discussion}

Statistical analysis and response surfaces. Table 2 summarizes the results of the ANOVA for each of the dependent variables with their corresponding coefficients of multiple determination $\left(R^{2}\right)$. The three independent variables had effects on film properties. TS $\left(y_{2}\right)$ and TSM $\left(y_{5}\right)$ had significant lack of fits $(P<0.05)$ but had sufficiently high $R$-square values to indicate that the data were adequately explained. The TS and TSM models were considered approximate and can be used for trend analysis. 3D response surfaces (Figures $1-3)$, generated by the regression equations of Table 2 , show effects of sorbitol, glycerin, and sorghum wax on prescribed film properties.

WVP. Three factors influenced WVP of SPI film. The shape of the response surface (Fig. 1) was characteristic of the interaction of three variables. The lowest WVP values were observed at the lowest concentration of sorbitol. Generally speaking and as would be expected, the lowest WVP was obtained with the $30 \%$ (w/w SPI) sorghum wax. The addition of sorbitol gave lower WVP values compared to glycerin-plasticized whey protein films (15) or starch films (16), but even the absences of glycerin and sorbitol did not decrease the WVP in this study. This result could have been due to the nonwax components of the ethanol-extracted sorghum wax. It likely contained some hydrophilic materials. The outer surface of the cuticle of grain sorghum kernels is covered with epicuticular waxes that can take diverse forms. Intracuticular waxes are embedded in the cutin polymer and little information is available on their composition. Wattendorf and Holloway (17) reported that plant cuticles also contain nonlipid, hydrophilic constituents such as polysaccharides. Although previous reports were related to leaves and fruits, it is highly probable that wax extracted using ethanol contained hydrophilic constituents. Therefore, it is assumed that sorbitol or glycerin molecules have linked with hydrophilic materials of wax or try to occupy the hydrophilic sites of protein competitively.

At the low concentration of sorbitol, glycerin did not affect WVP. Otherwise, glycerin increased the WVP at the high concentration of sorbitol. Sorghum wax concentration decreased the WVP. Lipids or waxes are effective water vapor barriers. The lowest WVP value of $2.23 \times 10^{-6} \mathrm{~g} \cdot \mathrm{m} / \mathrm{m}^{2} \cdot \mathrm{h} \cdot \mathrm{Pa}$ was obtained at the fifth design point. It was lower than the lowest value of $4.6 \times 10^{-6} \mathrm{~g}$ and $3.4 \times 10^{-6} \mathrm{~g} \cdot \mathrm{m} / \mathrm{m}^{2} \cdot \mathrm{h} \cdot \mathrm{Pa}$ reported for soy protein/FA and soy protein/lipid emulsified film, respectively (2). However, it was higher than whey protein-lipid emulsion films and wax films (4). 
Table 2. Regression Coefficients and Analyses of Variance ${ }^{a}$

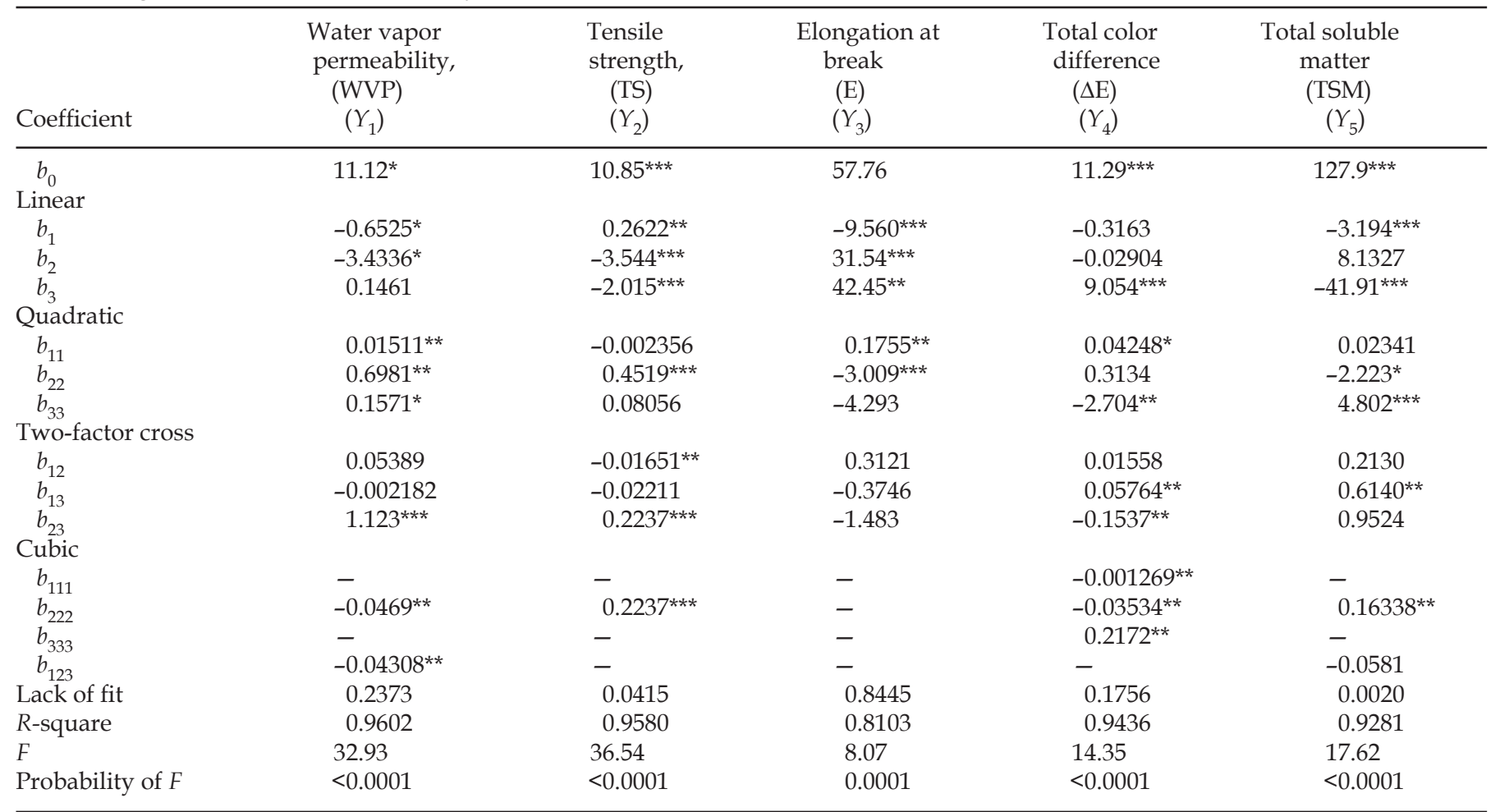

a. Model for analysis of property values $(Y)$ used $X_{1}=$ sorghum wax concentration (\%, w/w soy protein), $X_{2}=\mathrm{g}$ of glycerin in $5 \mathrm{~g}$ of soy protein, and $X_{3}=\mathrm{g}$ of sorbitol in $5 \mathrm{~g}$ of soy protein, and $Y=b_{0}+b_{1} X_{1}+b_{2} X_{2}+b_{3} X_{3}+b_{12} X_{1} X_{2}+b_{13} X_{1} X_{3}+b_{23} X_{2} X_{3}+b_{123} X_{1} X_{2} X_{3}+b_{11} X_{1}{ }^{2}+$ $b_{22} X_{2}{ }^{2}+b_{33} X_{3}{ }^{2}+b_{111} X_{1}{ }^{3}+b_{222} X_{2}{ }^{3}+b_{333} X_{3}{ }^{3}$.

* Significant at $10 \%$ level; ** significant at $5 \%$ level; *** significant at $1 \%$ level

TS. Increasing the sorbitol and glycerin contents decreased film TS. Decreases in TS with increases in plasticizer concentration have been reported for whey protein isolate films plasticized with sorbitol and glycerol together (15);

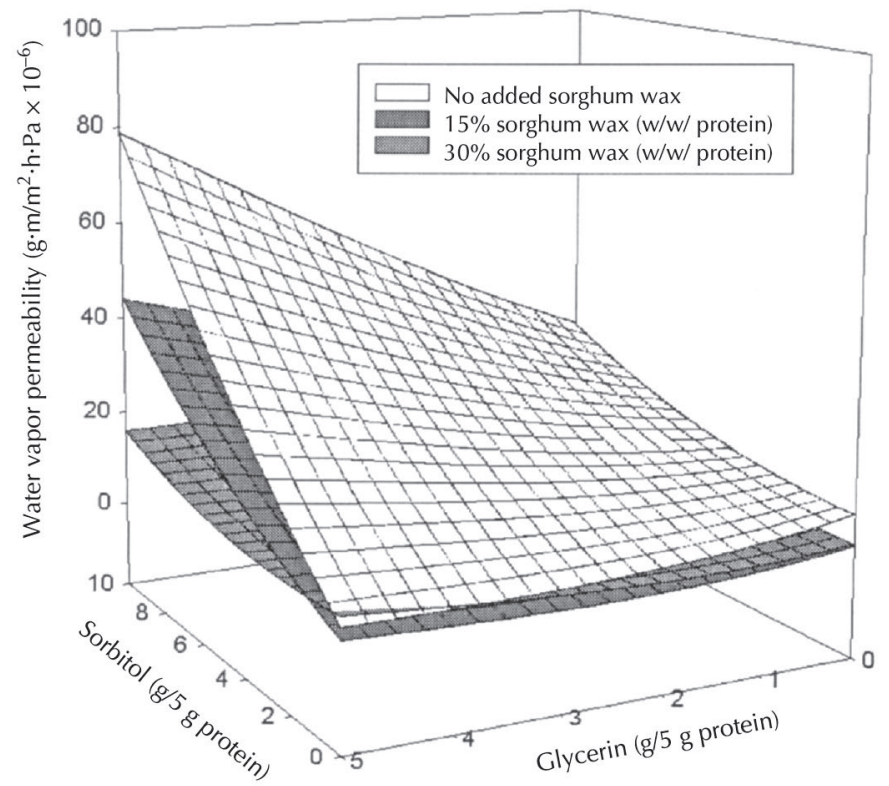

Figure 1. Response surface for the effects of sorbitol and glycerin concentrations on the water vapor permeability of sorghum waxsoy protein isolate composite films. for egg albumen films plasticized with sorbitol, glycerol, or polyethylene glycol (18); and for films made from gelatin, soluble starch, and polyols (19). However, increases in TS were reported with increases in sorbitol concentration for

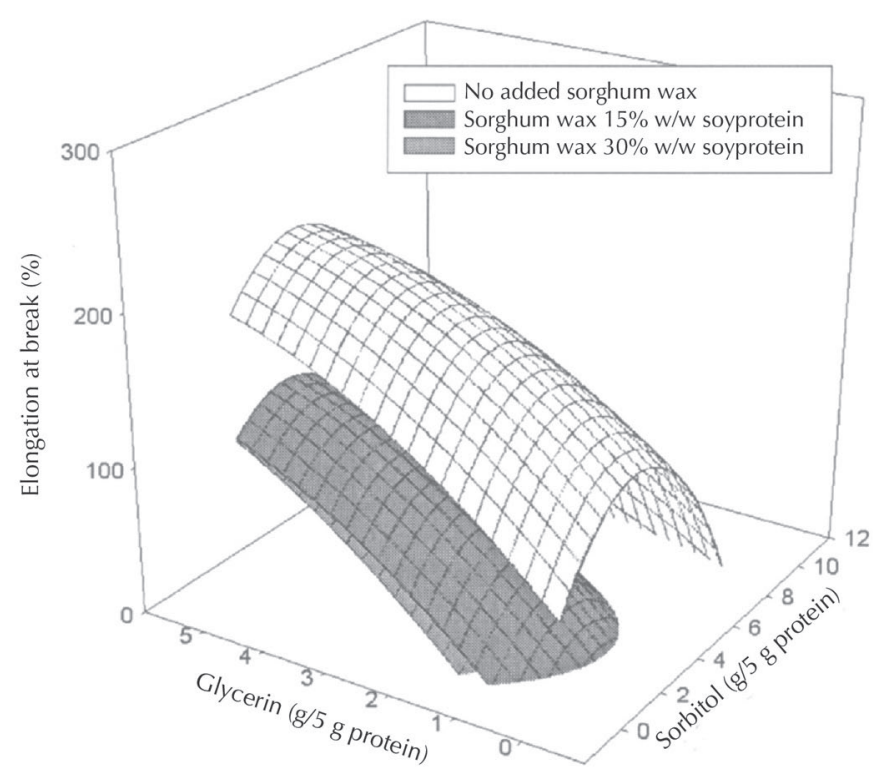

Figure 2. Response surface for the effects of sorbitol and glycerin concentrations on the elongation at break (\%) of sorghum waxsoy protein isolate composite films. 


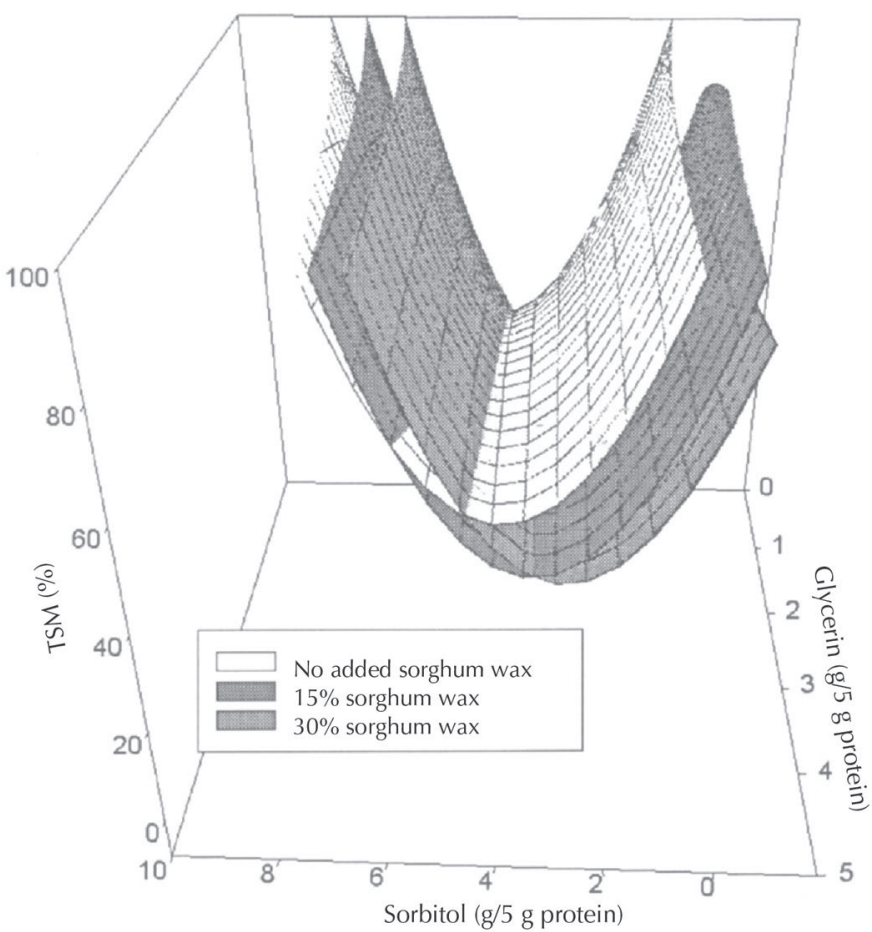

Figure 3. Response surface for the effects of sorbitol and glycerin concentrations on the total soluble matter (TSM) of sorghum waxsoy protein isolate composite films.

lactic acid- and rennet-precipitated casein-based films (8). Sorbitol may have resulted in decreased TS strength when it was used with other plasticizers. The sorghum wax, glycerin, and sorbitol used in this study may not have linked with each other or may not have cooperated to improve film structural integrity. High TS would be expected at low levels of glycerin and sorbitol. TS of films at the fifth and eleventh design points were 7.60 and 9.42 $\mathrm{MPa}$, respectively (Table 1). These values were much higher than those for films made from oils/waxes and zein (20), or soy protein and FA (2).

Elongation at break (\%). Addition of sorghum wax decreased film E, but the level of the addition did not affect it. The response surface showed that glycerin increased the E value, but sorbitol had a critical concentration of approximately $2 \mathrm{~g} / 5 \mathrm{~g}$ SPI (Fig. 2). Increases in E values with increasing concentration of plasticizers were reported for whey protein (15), egg albumen (18), and gelatin-soluble starch films (19). Generally, increasing TS accompanies decreasing elongation in films. However, the decrease in elongation of specimens of low TS may have been caused by excess amounts of sorbitol that weakened films so that they were easily torn during Instron tests.

$\Delta E$. Response surface analysis indicated that $\Delta \mathrm{E}$ values were of the highest value near the central points. Ranges of $L, a$, and $b$ values near the central points were 87.8-92.4, -2.57-4.53, and 9.38-20.38, respectively. The $b$ values varied drastically with film composition.

TSM. TSM decreased for sorbitol levels of 4.5, 3.5, and 2.5 $\mathrm{g} / 5 \mathrm{~g}$ SPI at sorghum wax levels of 0,15 , and $30 \%$, respectively. As the concentration of sorghum wax increased, the lowest value of TSM shifted to a lower value (Fig. 3). Glyc- erin was not effective at all in changing the TSM or else was much less effective than other factors in this study. Interestingly, TSM had its lowest values at a sorbitol level of approximately $2 \mathrm{~g} / 5 \mathrm{~g}$ protein. This result related well to the response surface of the E value.

Implications. The proposed use of an unrefined wax in place of a refined wax in SPI films to reduce costs and improve film structural integrity appears validated. Generally, film properties of SPI films with added sorghum wax paste were similar to or better than those with no wax or refined wax. For example, WVP was lower for SPI films with sorghum wax paste than SPI films with other added refined lipid materials. The increased TS of SPI films with added sorghum wax paste over TS of SPI films with other added lipid materials may be attributed to the increased structural integrity afforded by the sorghum wax paste.

Acknowledgments - Journal Series No. 13583, Agricultural Research Division, Institute of Agriculture and Natural Resources, University of Nebraska-Lincoln.

\section{References}

1. Ghorpade, V. M., A. Gennadios, M. A. Hanna, and C. L. Weller, Soy Protein Isolate/Poly (ethylene oxide) Films, Cereal Chem. 72:559-563 (1995).

2. Rhim, J-W., Y. Wu, C. L. Weller, and M. Schnepf, Physical Characteristics of Emulsified Soy Protein-Fatty Acid Composite Films, Sci. Aliments 19:57-71 (1999).

3. Avena-Bustillos, R. J., and J. M. Krochta, Water Vapor Permeability of Caseinate-Based Edible Films as Affected by $\mathrm{pH}$, Calcium Crosslinking and Lipid Content, J. Food Sci. 58:904-907 (1993).

4. Shellhammer, T. H., and J. M. Krochta, Whey Protein Emulsion Film Performance as Affected by Lipid Type and Amount, Ibid. 62:390-394 (1997).

5. Gontard, N., S. Marchesseau, J-L. Cuq, and S. Guilbert, Water Vapour Permeability of Edible Bilayer Films of Wheat Gluten and Lipids, Int. J. Food Sci. Technol. 30:49-56 (1995).

6. Lai, H. M., G. W. Padua, and L. S. Wei, Properties and Microstructure of Zein Sheets Plasticized with Palmitic and Stearic Acids, Cereal Chem. 74:83-90 (1997).

7. Kim, K. M., K. T. Hwang, C. L. Weller, and M. A. Hanna, Preparation and Characterization of Soy Protein Isolate Films Modified with Sorghum Wax, J. Am. Oil. Chem. Soc. 79:615-619 (2002).

8. Chick, J., and Z. Ustunol, Mechanical and Barrier Properties of Lactic Acid and Rennet Precipitated Casein-Based Edible Films, J. Food Sci. 63:1024-1027 (1998).

9. Box, G. E. P., W. G. Hunter, and J. S. Hunter, Statistics for Experiments, John Wiley \& Sons, New York, 1978.

10. SAS Institute, SAS/STAT User's Guide, version 6, 4th ed., Cary, NC, 1990.

11. ASTM, Standard Test Methods for Tensile Properties of Thin Plastic Sheeting (D882-91), in Annual Book of ASTM Standards, American Society for Testing and Materials, West Conshohocken, PA, 1995, Vol. 8.01, pp. 182-190.

12. Rhim, J. W., A. Gennadios, C. L. Weller, C. Cezeirat, and M. A. Hanna, Soy Protein Isolate-Dialdehyde Starch Films, Ind. Crops Prod. 8:195-203 (1998). 
13. ASTM, Standard Test Methods for Water Vapor Transmission of Materials (E96-95), in Annual Book of ASTM Standards, American Society for Testing and Materials, West Conshohocken, PA, 1995, Vol. 4.06, pp. 697-704.

14. Gennadios, A., C. L. Weller, and C. H. Gooding, Measurement Errors in Water Vapor Permeability of Highly Permeable, Hydrophilic Edible Films, J. Food Eng. 21:395-409 (1994).

15. McHugh, T. H., and J. M. Krochta, Sorbitol- vs. Glycerol-Plasticized Whey Protein Edible Films: Integrated Oxygen Permeability and Tensile Property Evaluation, J. Agric. Food Chem. 42:841-845 (1994).

16. Garcia, M. A., M. N. Martino, and N. E. Zaritzky, Lipid Addition to Improve Barrier Properties of Edible Starch-based Films and Coatings, J. Food Sci. 65:941-947 (2000).
17. Wattendorf, J., and P. J. Holloway, Studies on Ultrastructure and Histochemistry of Plant Cuticles: The cuticular Membrane of Agave americana L. in situ, Ann. Bot. 46:13-28 (1980).

18. Gennadios, A., C. L. Weller, M. A. Hanna, and G. W. Froning, Mechanical and Barrier Properties of Egg Albumen Films, J. Food Sci. 61:585-589 (1996).

19. Arvanitoyannis, I., E. Psomiadou, A. Nakayama, S. Aiba, and N. Yamamoto, Edible Films Made from Gelatin, Soluble Starch and Polyols, Part 3, Food Chem. 60:593-604 (1997).

20. Weller, C. L., A. Gennadios, and R. A. Saraiva, Edible Bilayer Films from Zein and Grain Sorghum Wax or Carnauba Wax, Lebensm. Wiss. Technol. 31:279-285 (1998). 